\title{
LAHAN BASAH BUATAN SEBAGAI MEDIA PENGOLAHAN AIR LIMBAH BUDIDAYA UDANG VANAME (Litopenaeus vannamaei) BERSALINITAS RENDAH (Constructed Wetland for Remediation of Brackish Wastewater from White Shrimp (Litopenaeus vannamaei) Cultivation)
}

\author{
Syafrudin Raharjo ${ }^{1,2, *}$, Suprihatin ${ }^{3}$, Nastiti S. Indrasti ${ }^{3}$, Etty Riani ${ }^{4}$, Supriyadi ${ }^{5}$ dan \\ Warih Hardanu ${ }^{5}$ \\ ${ }^{1}$ Program Studi Pengelolaan Sumberdaya Alam dan Lingkungan Institut Pertanian Bogor \\ Kampus Baranangsiang Jl. Raya Pajajaran, Bogor 16127. \\ ${ }^{2}$ Universitas Negeri Papua, Jl. Gunung Salju, Amban Manokwari Papua Barat 98314. \\ ${ }^{3}$ Teknologi Industri Pertanian Institut Pertanian Bogor Jl. Raya Darmaga Bogor 16680. \\ ${ }^{4}$ Manajemen Sumberdaya Perairan Institut Pertanian Bogor Jl. Raya Darmaga Bogor 16680. \\ ${ }^{5}$ Balai Layanan Usaha Produksi Perikanan Budidaya (BLUPPB) Desa Pusakajaya Utara, \\ Kecamatan Cilebar Kabupaten Karawang Jawa Barat 41353. \\ *Penulis korespondensi. No Tel.081344446465. Email: syaf04@yahoo.com.
}

Diterima: 10 Februari 2015

Disetujui: 25 Maret 2015

\begin{abstract}
Abstrak
Air limbah budidaya udang berjumlah relatif banyak dan mengandung bahan pencemar yang berpotensi mencemari lingkungan. Di sisi lain, air limbah tersebut dapat diolah dan diresirkulasi dalam sistem budidaya udang. Tujuan penelitian ini adalah untuk menyelidiki kemampuan sistem lahan basah buatan-aliran air permukaan (LBBAAP) yang ditanami dengan rumput vetiver (Chrysopogon zizanioides, L) dalam menghilangkan pencemar $\left(\mathrm{NO}_{2}^{-}, \mathrm{NO}_{3}^{-}\right.$ , $\mathrm{NH}_{3}, \mathrm{NH}_{4}{ }^{+}$dan $\mathrm{PO}_{4}{ }^{3-}$ ) dari air limbah budidaya udang vaname (Litopenaeus vannamaei) kondisi mesohaline dan mengevaluasi kinerja sistem tersebut. Hasil penelitian menunjukkan bahwa sistem LBB-AAP mampu mengeliminasi parameter $\mathrm{NO}_{2}{ }^{-}, \mathrm{NO}_{3}{ }^{-}, \mathrm{NH}_{3}, \mathrm{NH}_{4}{ }^{+}$dan $\mathrm{PO}_{4}{ }^{3-}$ secara signifikan. Rumput vetiver mampu tumbuh pada kondisi mesohaline dan dapat melakukan remediasi air limbah tersebut. Serapan rumput vetiver dalam sistem LBB-AAP untuk $\mathrm{NO}_{3}^{-}, \mathrm{NH}_{4}{ }^{+}$ dan $\mathrm{PO}_{4}{ }^{3-}$ adalah 28, 63 dan $83 \%$. Desain konstruksi LBB-AAP tipe Hidroponik menunjukkan kinerja terbaik dalam pengendalian air limbah budidaya udang vaname dibandingkan dengan tipe emergent, kombinasi hidroponik dan emergent.
\end{abstract}

Kata kunci: air limbah, budidaya udang, lahan basah buatan, rumput vetiver, udang vaname.

\begin{abstract}
The amount of wastewater shrimp cultivation is relatively/too much, contains a variety of pollutants and potentially pollute the environment. In other side, The wastewater can be treated and also recirculated in shrimp cultivation systems. The purpose of research is to investigate the ability of flow water surface-constructed wetland system (FWS-CWs) that planted vetiver grass (Chrysopogon zizanioides, L) that removes of pollutants $\left(\mathrm{NO}_{2}^{-}\right.$, $\mathrm{NO}_{3}^{-}$, $\mathrm{NH}_{3}, \mathrm{NH}_{4}^{+}$and $\mathrm{PO}_{4}^{3-}$ ) from wastewater vaname shrimp cultivation (Litopenaeus vannamaei) on conditions mesohaline and with the aim of evaluating the performance of the system. The results of the research indicate that FWS-CWs able to eliminate the parameters significantly of $\mathrm{NO}_{2}^{-}, \mathrm{NO}_{3}^{-}, \mathrm{NH}_{3}, \mathrm{NH}_{4}{ }^{+}$and $\mathrm{PO}_{4}{ }^{3-}$. Vetiver grass could grow on mesohaline conditions and it can perform remediation of the wastewater. Uptake of vetiver grass in $\mathrm{FWS}-\mathrm{CWs}_{\mathrm{S}}$ system for $\mathrm{NO}_{3}{ }^{-}$, $\mathrm{NH}_{4}^{+}$dan $\mathrm{PO}_{4}^{3-}$ is 28, 63 and $83 \%$. Construction design FWS-CWs with Hydroponics type provide the best performance in the control of wastewater vaname shrimp cultivation when compared with emergent type and a combination of hydroponics-emergent.
\end{abstract}

Keywords: constructed wetland, vaname shrimp, vetiver grass, wastewater shrimp cultivation.

\section{PENDAHULUAN}

Usaha perikanan budidaya Indonesia merupakan salah satu sektor penting dalam peningkatan produksi perikanan. Produksi perikanan budidaya tahun 2013 memberikan kontribusi sebesar $68,54 \%$ dari total produksi perikanan nasional (Anonim, 2014). Peningkatan kegiatan usaha budidaya perikanan ini selain berdampak positif juga memberikan dampak negatif. Dampak negatif yang dapat ditimbulkan adalah terlampauinya daya dukung perairan, terganggunya kehidupan organisme perairan dan terjadi salinisasi tanah serta kehilangan vegetasi hutan mangrove. Air limbah budidaya perikanan berupa peningkatan limbah cair dan lumpur atau endapan dari feses dan sisa pakan (Anonim, 2011; 
Boyd, 2003). Dampak lainnya berupa deplesi oksigen dan eutrofikasi (Naylor dkk., 2000).

Mengingat kegiatan budidaya perikanan membutuhkan air yang sangat banyak dan kenyataannya bahwa kondisi kualitas air sebagai sumber air semakin buruk serta adanya isu global bahwa pengembangan budidaya perikanan harus berkelanjutan (Lin dan Yang, 2003), maka pengolahan dan resirkulasi air limbah budidaya udang menjadi pilihan yang prospektif.

Pengolahan Air Limbah Budidaya Perikanan (ALBP) dapat dilakukan dengan berbagai cara, antara lain dengan melakukan penambahan mikroba positif untuk membantu memperbaiki kualitas air kolam, sistem biofilter, resirkulasi, teknologi bioflok, bioremediasi, atau kombinasi dari beberapa metode tersebut (Avnimelech, 2006; Avnimelech dan Malka, 2009; Crab dkk., 2007; Dumas dkk., 1998; Pan dkk., 2007; Piedrahita, 2003; Ray dkk., 2010; Ridha dan Cruz, 2001; Schryver dkk., 2008; True dkk., 2004; Twarowska dkk., 1997). Namun demikian teknologi tersebut belum banyak diterapkan khususnya oleh pelaku budidaya ikan skala menengah dan kecil. Hal tersebut disebabkan oleh teknologi tersebut yang memerlukan tenaga dan keahlian khusus, serta meningkatkan biaya produksi secara signifikan.

Teknologi yang murah, mudah dan efektif dalam pengendalian ALBP adalah teknologi Lahan Basah Buatan (LBB). LBB adalah lahan basah yang sengaja dibuat, mudah konstruksinya, dikelola dan dikontrol oleh manusia untuk keperluan filtrasi air limbah dengan memadukan penggunaan tanaman dan aktivitas mikroba. Dilaporkan bahwa sistem ini efektif dalam pengurangan Biological Oxygen Demand (BOD), SS, N, dan P serta untuk mengurangi logam, polutan organik, dan patogen dari air limbah (Crites dkk., 2006; Kadlec dan Wallace, 2009; Tchobanoglous dkk., 2003; Wang dkk., 2010).

Rumput vetiver (Chrysopogon zizanioides, L) digunakan dalam sistem LBB karena vetiver mempunyai kemampuan hidup dalam cakupan kondisi yang sangat beragam dan luas, baik terhadap kondisi iklim, habitat, dan kualitas air serta perairan bersalinitas. Vetiver juga memiliki persen penghilangan tinggi untuk $\mathrm{N}$ dan $\mathrm{P}$ dari limbah cair (Truong dan Hart, 2001; Truong dan Loch, 2004; Truong dkk., 2008; Vimala dan Kataria, 2004;).

Tujuan penelitian ini adalah mengkaji kemampuan sistem LBB yang ditanami dengan rumput vetiver (C. zizanioides, $\mathrm{L}$ ) untuk mengeliminasi pencemar dalam air limbah budidaya udang vaname (Litopenaeus vannamaei) pada kondisi bersalinitas mesohaline. Pengolahan air limbah dengan sistem LBB Aliran Air
Permukaan (LBB-AAP) dan menggunakan rumput vetiver (C. zizanioides, L) diharapkan dapat menjadi alternatif solusi yang efektif untuk pengolahan air limbah budidaya udang vaname yang berkelanjutan.

\section{METODE PENELITIAN}

Lokasi penelitian di Balai Layanan Usaha Produksi Perikanan Budidaya (BLUPPB) Karawang di Dusun Sukajadi, Desa Pusakajaya utara, Kecamatan Cilebar Kabupaten Karawang Jawa Barat. Analisis laboratorium dilakukan di Laboratorium BLUPPB Karawang dan Laboratorium Tanah Fakultas Pertanian IPB Bogor.

Bahan yang digunakan untuk media lahan basah berupa pasir kasar (sirtu), koral dan styrofoam. Tanaman yang digunakan adalah rumput vetiver (C. zizanioides, L). Penyediaan bibit rumput vetiver dilakukan melalui dua tahapan, yakni penyediaan stok anakan secara vegetatif (reproduksi aseksual) dengan metode "Splitting Mature Plants" dan dipelihara selama 45 hari. Tahap berikutnya adalah perbanyakan stok bibit dengan memindahkan bibit ke dalam wadah ukuran satu liter dan menggunakan media campuran tanah dan kompos dengan perbandingan (1:1) dan dipelihara selama 45 hari.

Air limbah yang digunakan untuk penelitian berasal dari kegiatan budidaya udang vaname (L.vannamaei) dengan padat tebar $100 \mathrm{ekor} / \mathrm{m}^{2}$. Umur tebar udang (benur) adalah post larva 10 hari (PL-10) dan dipelihara selama tiga bulan. Polutan utama air limbah berasal dari sisa pakan dan feses selama kegiatan pemeliharaan udang vaname. Pakan yang diberikan selama penelitian memiliki komposisi protein $42 \%$, serat kasar 3\%, lemak $6 \%$, kadar air $12 \%$, dan abu $13 \%$.

Kolam yang digunakan untuk penelitian berupa bak plastik vynil dari spanduk bekas dengan konstruksi bambu berukuran $7 \mathrm{~m} \times 3 \mathrm{~m} \times 1 \mathrm{~m}$ (volume $21 \mathrm{~m}^{3}$ ). Air limbah dialirkan ke LBB-AAP secara kontinyu selama dua bulan setelah umur udang mencapai umur 1 bulan. Ada empat tipe desain LBB-AAP yang diteliti, yaitu tipe Emergent (E), Hidroponik $(\mathrm{H})$, Hidroponik + Emergent (HE) dan kontrol (K). Ukuran LBB-AAP $2 \mathrm{~m}$ x $1 \mathrm{~m}$ x 0,5 $\mathrm{m}$, berupa bak plastik vynil dari spanduk bekas dengan konstruksi bambu. Deskripsi masingmasing tipe disajikan pada Tabel 1. Masing-masing LBB-AAP ditanami rumput vetiver sebanyak 36 bibit/rumpun ( \pm 3 batang/rumpun) dengan jarak tanam $15 \mathrm{~cm}$.

Percobaan dilakukan dengan dua ulangan. Gambar 1 menunjukkan tata letak satuan percobaan. Empat perlakuan tersebut dibandingkan antar perlakuan yang diterapkan untuk sistem LBB- 
Tabel 1. Deskripsi tipe desain LBB-AAP.

\begin{tabular}{|c|c|c|}
\hline Tipe desain & Kode & Deskripsi \\
\hline Emergent & $\mathrm{E}$ & $\begin{array}{l}\text { Vetiver ditanam di dasar dan } \\
\text { menyembul di atas permukaan } \\
\text { air dengan media pasir kasar } \\
\text { bersekat koral. }\end{array}$ \\
\hline Hidroponik & $\mathrm{H}$ & 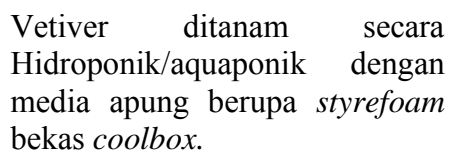 \\
\hline $\begin{array}{l}\text { Hidroponik } \\
\text { +Emergent }\end{array}$ & $\mathrm{HE}$ & $\begin{array}{l}\text { Merupakan perlakuan kombinasi } \\
\text { Hidroponik-Emergent. }\end{array}$ \\
\hline Kontrol & K & $\begin{array}{l}\text { Vetiver ditanam secara } \\
\text { Emergent dengan media pasir } \\
\text { kasar. }\end{array}$ \\
\hline
\end{tabular}

AAP. Perhatian utama diberikan pada tingkat efisiensi sistem LBB-AAP dengan rumput vetiver (C. zizanioides, L) dalam mengeliminasi konsentrasi pencemar seperti amoniak $\left(\mathrm{NH}_{3}\right)$, amonium $\left(\mathrm{NH}_{4}^{+}\right)$, nitrit $\left(\mathrm{NO}_{2}^{-}\right)$, nitrat $\left(\mathrm{NO}_{3}{ }^{-}\right)$dan fosfat $\left(\mathrm{PO}_{4}^{3-}\right)$. Analisis laboratorium parameter pencemar dilakukan sesuai dengan prosedur APHA 2005 dan SNI yang dilakukan di laboratorium BLUPPB Karawang dan Laboratorium Tanah IPB Bogor.

Penelitian dilakukan selama tiga bulan, dan diatur pada taraf waktu tinggal (t) atau hydraulic retention time (HRT) tiga hari dengan debit air limbah (aquaculture effluents) rata-rata adalah 0,65 $\mathrm{L} /$ menit atau $233,33 \mathrm{~L} / \mathrm{hari}$.

Tingkat efisiensi LBB-AAP dalam melakukan penghilangan digunakan persamaan sebagai berikut (Spellman, 2004):

$\%$ Penghilangan $=$ $\frac{\text { [Konsentrasi influent-Konsentrasi Effluent] }}{\text { Konsentrasi Influent }} \times 100$
Pengukuran kemampuan pengambilan $\mathrm{NO}_{3}{ }^{-}$, $\mathrm{NH}_{4}{ }^{+}$dan $\mathrm{PO}_{4}{ }^{3-}$ oleh tanaman dihitung dengan menghitung beban limbah rerata (BL), yakni debit limbah $\left(\mathrm{Q}_{\text {limbah }}\right)$ dikalikan dengan konsentrasi limbah $\left(\mathrm{C}_{\text {limbah }}\right)$.

$\mathrm{BL}=\mathrm{Q}_{\text {limbah }}(\mathrm{L} /$ hari $) \times \mathrm{C}_{\text {limbah }}(\mathrm{mg} / \mathrm{L})$

BL kemudian dikalikan dengan $\%$ kemampuan pengambilan rerata rumput vetiver (rv) untuk masing-masing kondisi.

$\mathrm{KU}=\mathrm{BL}$ (mg/hari) x rv (\%)

Perbedaan antar perlakuan diuji untuk melihat signifikansi dengan menggunakan analisis varians (ANOVA) dua arah dan Uji Fisher 95\%.

Analisis Rank and Percentile (RaP) digunakan untuk menentukan urutan perlakuan terbaik terhadap semua parameter, yakni $\mathrm{NH}_{3}, \mathrm{NH}_{4}{ }^{+}, \mathrm{NO}_{2}{ }^{-}$, $\mathrm{NO}_{3}^{-}$dan $\mathrm{PO}_{4}^{3-}$. Pembuatan urutan perlakuan terbaik dilakukan melalui penentuan rangking dan persentil dari ke lima parameter. Selanjutnya dilakukan perhitungan skor dengan melakukan perkalian antara nilai efisiensi dengan persentil dan kemudian dihitung nilai total untuk masing-masing perlakuan. Urutan perlakuan terbaik didasarkan pada nilai tertinggi hingga terendah.

\section{HASIL DAN PEMBAHASAN}

\section{Performa Sistem LBB-AAP}

Sistem LBB-AAP dengan rumput vetiver (C. zizanioides, L) digunakan sebagai biofilter pengolahan air limbah budidaya udang vaname (L.vannamaei) dalam kondisi mesohaline (5-15 $\%$ o). Selama penelitian beban bahan pencemar ratarata untuk $\mathrm{NO}_{2}^{-}, \mathrm{NO}_{3}^{-}, \mathrm{NH}_{3}, \mathrm{NH}_{4}^{+}$dan $\mathrm{PO}_{4}^{3-}$ adalah $0,49,5,54,4,0,0,07$ dan 2,94 $\mathrm{g}$ /hari.

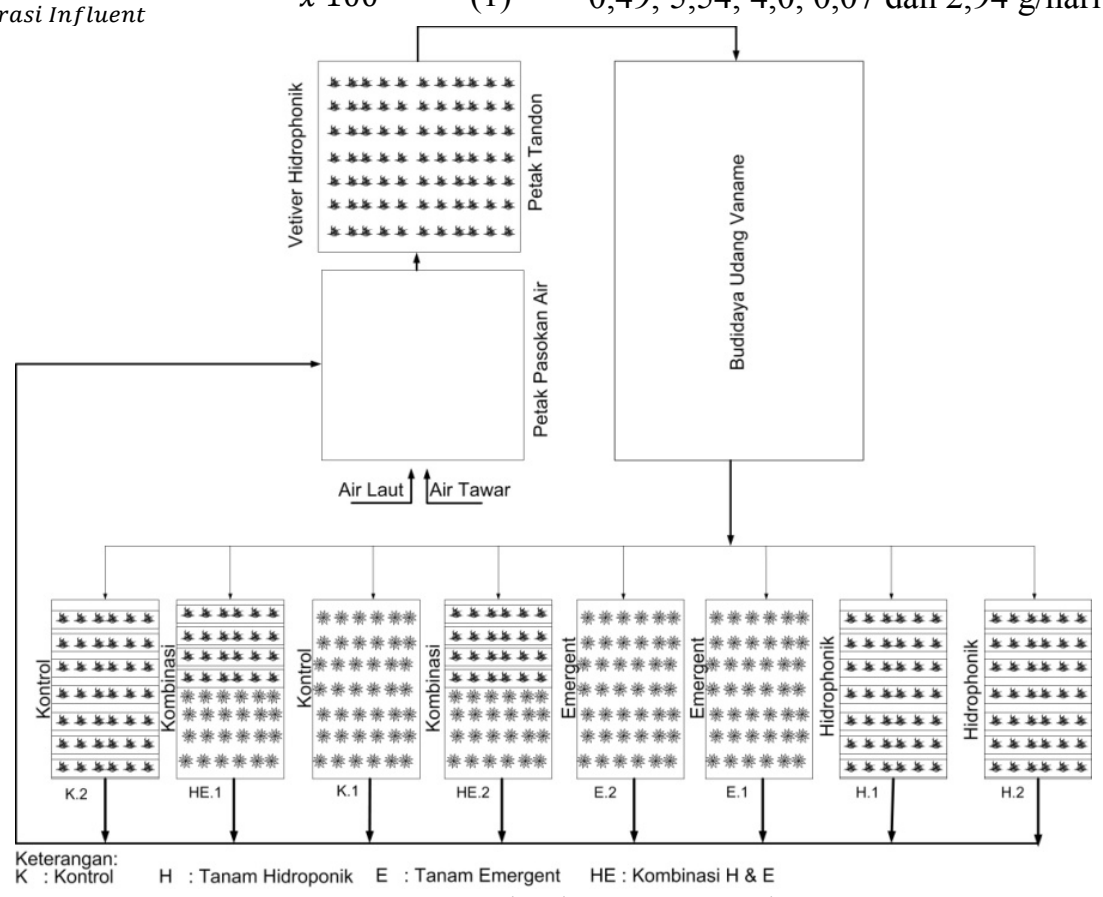

Gambar 1. Tata letak satuan percobaan. 
Tabel 2. Kemampuan penghilangan pencemar sistem LBB-AAP.

\begin{tabular}{cccccc}
\hline Perlakuan & $\mathrm{NH}_{3}(\%)$ & $\mathrm{NH}_{4}^{+}(\%)$ & $\mathrm{NO}_{2}^{-}(\%)$ & $\mathrm{NO}_{3}^{-}(\%)$ & $\mathrm{PO}_{4}{ }^{-}-(\%)$ \\
\hline $\mathrm{K}$ & $43,8 \pm 3,4$ & $46,9 \pm 5,8$ & $61,0 \pm 0,7$ & $68,0 \pm 5,7$ & $17,5 \pm 3,7$ \\
$\mathrm{HE}$ & $37,1 \pm 4,6$ & $41,9 \pm 8,2$ & $65,9 \pm 3,9$ & $73,1 \pm 3,7$ & $13,6 \pm 4,0$ \\
$\mathrm{E}$ & $43,8 \pm 10,5$ & $52,1 \pm 8,0$ & $51,0 \pm 5,6$ & $59,0 \pm 12,9$ & $18,4 \pm 1,6$ \\
$\mathrm{H}$ & $40,8 \pm 6,9$ & $50,4 \pm 5,7$ & $91,3 \pm 12,1$ & $77,8 \pm 0,0$ & $14,3 \pm 2,6$ \\
\hline
\end{tabular}

Berbagai proses dapat terjadi dalam penghilangan pencemar di LBB-AAP, yakni mineralisasi oleh mikroba, transformasi (nitrifikasidenitrifikasi) dan serapan oleh tanaman (Wang dkk., 2010; Truong dkk., 2008; Tchobanoglous dkk., 2003). Secara umum, performa penghilangan pencemar sangat bervariasi dan sangat tergantung pada jenis pencemar, tipe desain konstruksi LBBAAP dan umur rumput vetiver (C. zizanioides, $\mathrm{L}$ ). Performa penghilangan pencemar yang diamati, yakni $\mathrm{NO}_{2}^{-}, \mathrm{NO}_{3}^{-}, \mathrm{NH}_{3}, \mathrm{NH}_{4}^{+}$dan $\mathrm{PO}_{4}^{3-}$ berturutturut nilainya berkisar antara $51-91,3 \%, 59-$ $77,8 \%, 37,1-43,8 \%, 41,9-50,4 \%$ dan $13,6-$ $18,4 \%$. Kemampuan sistem LBB-AAP dapat dilihat pada Tabel 2 .

Performa penghilangan pencemar $\mathrm{NO}_{3}^{-}, \mathrm{NH}_{4}^{+}$, $\mathrm{PO}_{4}{ }^{3-}$ oleh serapan rata-rata rumput vetiver $(C$. zizanioides, L) baik di akar maupun di daun, berturut-turut adalah 28,0, 63,2 dan 82,8 \% dari efisiensi LBB-AAP. Ini menunjukkan bahwa rumput vetiver berkontribusi terhadap penghilangan pencemar dalam sistem LBB-AAP.

Tanaman memainkan peran yang sangat penting dalam LBB-AAP. Mereka menaungi kolom air, memberikan ruang untuk pertumbuhan biofilm, dan bantuan daur hara dan karbon organik (Kadlec dan Wallace, 2009). Tanaman lahan basah memainkan berbagai peran di LBB untuk pengolahan air limbah. Peran utama dari tanaman adalah menyediakan luas permukaan untuk pertumbuhan mikroba (biofilm), sehingga meningkatkan proses penyisihan oleh mikroba termasuk nitrifikasi dan denitrifikasi. Tumbuhan juga memiliki peran metabolisme dalam pengolahan air limbah dengan potensi untuk melepaskan $\mathrm{O}_{2}$ ke akar untuk membantu nitrifikasi dan penyerapan langsung nutrisi (Brix, 1997; Greenway dan Woolley, 2001;). Tosepu (2012), tanaman yang memiliki akar yang bercabangcabang halus, permukaan akarnya digunakan oleh mikroorganisme sebagai tempat pertumbuhan.

Serapan $\mathrm{NH}_{4}^{+}$oleh rumput vetiver lebih tinggi dibandingkan dengan $\mathrm{NO}_{3}^{-}$, ini karena rumput vetiver lebih memilih sumber nitrogen dari $\mathrm{NH}_{4}{ }^{+}$ dibanding $\mathrm{NO}_{3}^{-}$(Tabel 3). Menurut Garnett dkk. (2003), berbagai jenis tumbuhan berbeda dalam bentuk sumber $\mathrm{N}$ yang disukai untuk diserap, tergantung pada sumber yang tersedia di lahan
Tabel 3. Penghilangan pencemar sub sistem rumput vetiver (C. zizanioides, L).

\begin{tabular}{cccc}
\hline Perlakuan & $\mathrm{NO}_{3}^{-}(\%)$ & $\mathrm{NH}_{4}^{+}(\%)$ & $\mathrm{PO}_{4}{ }^{-}(\%)$ \\
\hline $\mathrm{K}$ & 26,6 & 62,0 & 81,1 \\
$\mathrm{HE}$ & 26,0 & 67,4 & 87,2 \\
$\mathrm{E}$ & 28,6 & 61,8 & 89,0 \\
$\mathrm{H}$ & 30,9 & 61,6 & 74,1 \\
\hline Rerata & 28,0 & 63,2 & 82,8 \\
\hline
\end{tabular}

basah. Pada laporan lain, Fang dkk. (2007) menyebutkan bahwa tanaman mengambil nitrogen oleh akar dan daun. Jika kedua sumber $\mathrm{N}$ yang tersedia, maka tanaman lebih memilih untuk mengambil $\mathrm{NH}_{4}^{+}$.

\section{Efisiensi Penghilangan Pencemar}

Empat desain konstruksi LBB-AAP dan bertambahnya umur rumput vetiver (C. zizanioides, L) mampu menghilangkan pencemar dengan tingkat efisiensi yang beragam. Pencemar yang diamati meliputi $\mathrm{NH}_{3}, \mathrm{NH}_{4}^{+}, \mathrm{NO}_{2}^{-}, \mathrm{NO}_{3}^{-}$dan $\mathrm{PO}_{4}^{3-}$. Efisiensi masing-masing pencemar diuraikankan sebagai berikut.

\section{Efisiensi Penghilangan $\mathrm{NH}_{3}$}

Di antara parameter kualitas air yang mempengaruhi kehidupan udang budidaya, $\mathrm{NH}_{3}$ adalah parameter kedua paling penting setelah oksigen, terutama dalam sistem budidaya intensif. Hargreaves dan Tucker (2004), menyatakan bahwa akumulasi amonia bersifat racun terhadap organisme perairan. $\mathrm{NH}_{3}$ mudah terakumulasi dalam tambak karena merupakan produk sampingan dari metabolisme udang. $\mathrm{NH}_{3}$ dari kolam budidaya udang vaname sebagai sumber air limbah dapat mencapai $1,46 \mathrm{mg} / \mathrm{L}$ (rata-rata 0,49 $\mathrm{mg} / \mathrm{L})$.

Tingkat efisiensi rata-rata penghilangan limbah $\mathrm{NH}_{3}$ dalam LBB-AAP berkisar antara 37,14-43,83\%. Efisiensi penghilangan tertinggi terjadi pada konstruksi LBB-AAP dengan tipe desain Kontrol $(\mathrm{K})$ dan terendah pada LBB-AAP tipe kombinasi Hidroponik-Emergent (HE) (Gambar 2(a)).

Hasil analisis data statistik menunjukkan bahwa perlakuan tipe desain LBB-AP ternyata tidak berbeda nyata $(\mathrm{P}$ value $=0,798)$. Begitu pula perlakuan waktu operasi, ternyata tidak berbeda 


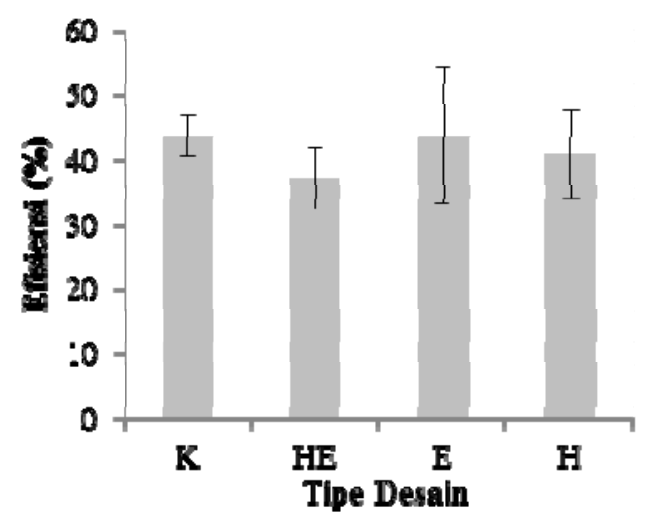

(a)

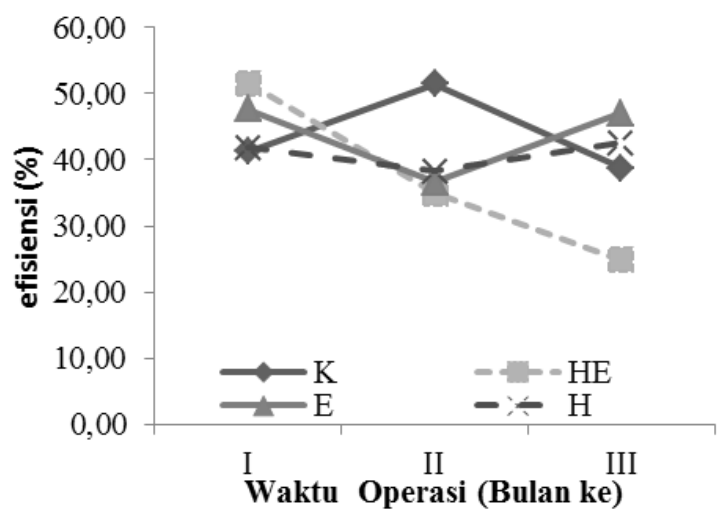

(b)

Gambar 2. (a) Tingkat efisiensi eliminasi $\mathrm{NH}_{3}$ (b) Variasi tingkat efisiensi eliminasi $\mathrm{NH}_{3}$ berdasarkan waktu operasi.

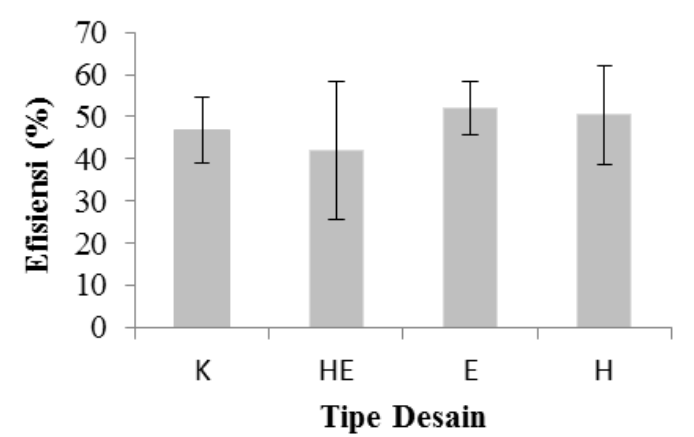

(a)

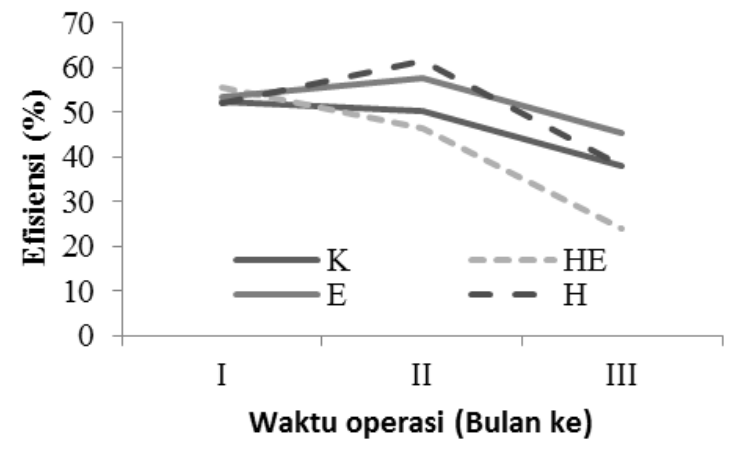

(b)

Gambar 3. (a) Tingkat efisiensi eliminasi $\mathrm{NH}_{4}{ }^{+}$(b) Variasi tingkat efisiensi eliminasi $\mathrm{NH}_{4}{ }^{+}$berdasarkan waktu operasi.

secara signifikan $(\mathrm{P}$ value $=0,545)$. Untuk interaksi antara tipe desain dan waktu operasi tidak menunjukkan interaksi yang signifikan $(\mathrm{P}$ value $=$ 0,585). Dari uraian tersebut dapat diberikan kesimpulan bahwa berdasarkan desain perlakuan $\mathrm{K}$ dan E lebih baik dibandingkan dengan perlakuan lain ( $\mathrm{H}$ dan $\mathrm{HE}$ ), secara berurutan tingkat efisiensi rata-ratanya adalah 43,$83 ; 43,79 ; 40,85$ dan 37,14 $\%$ (Gambar 2(a)).

Kemampuan penghilangan $\mathrm{NH}_{3}$ secara umum memiliki performa yang menurun dengan meningkatnya umur rumput vetiver kecuali untuk perlakuan H (Gambar 2b). Perlakuan K memiliki pola penurunan dari $41,27-38,74 \%$ (rata-rata 43,83\%), E memiliki trend penurunan yang kecil antara 47,67-47,04\% (rata-rata 43,79\%), $\mathrm{H}$ memiliki pola kenaikan dari $41,83-42,51 \%$ (ratarata $40,85 \%$ ), sedangkan perlakuan HE memiliki trend penurunan antara $51,63-24,89 \%$ (rata-rata $37,14 \%)$. Umumnya performa terbaik terjadi pada bulan ke satu waktu operasi kecuali pada perlakuan $\mathrm{H}$, di mana performa terus meningkat (Gambar 2(b)). Keadaan ini diduga karena beban limbah yang masuk ke LBB-AAP terus meningkat, sehingga kemampuan sistem LBB-AAP dengan

rasio 11:1 sudah tidak mampu lagi menerima beban limbah tersebut. Selain itu, karena tingginya limbah organik menyebabkan peningkatan proses perombakan bahan organik menjadi $\mathrm{NH}_{3}$ (amonifikasi meningkat). Akibatnya proses penghilangan oleh sistem LBB-AAP menurun dan kurang efisien. Reddy dan Patrick (1984), jika ammonifikasi berlangsung lebih cepat daripada nitrifikasi, maka keberadaan $\mathrm{NH}_{3}$ juga meningkat dibandingkan dengan $\mathrm{NO}_{2}^{-}$.

\section{Efisiensi Penghilangan $\mathrm{NH}_{4}^{+}$}

$\mathrm{NH}_{4}{ }^{+}$dan $\mathrm{NH}_{3}$ saling terkait. Konsentrasi relatif $\mathrm{NH}_{4}^{+}$dan $\mathrm{NH}_{3}$ pada dasarnya tergantung pada $\mathrm{pH}$ dan suhu air. Jika nilai $\mathrm{pH}$ dan suhu cenderung meningkat, konsentrasi $\mathrm{NH}_{3}$ juga meningkatkan dan konsentrasi $\mathrm{NH}_{4}{ }^{+}$menurun (Emerson dkk., 1975).

Tingkat efisiensi penghilangan $\mathrm{NH}_{4}^{+}$dalam LBB-AAP berkisar antara 41,9 - 52,1\%. Efisiensi penghilangan tertinggi terdapat pada konstruksi LBB-AAP dengan tipe desain Emergent (E) dan terendah terdapat pada LBB-AAP tipe kombinasi Hidroponik-Emergent (HE) (Gambar 3(a)). 
Hasil analisis data statistik menunjukkan bahwa keempat tipe desain LBB-AAP tidak berbeda nyata $(P$ value $=0,61)$. Perlakuan waktu operasi terhadap kemampuan eliminasi $\mathrm{NH}_{4}^{+}$ berpengaruh secara signifikan ( $\mathrm{P}$ value $=0,04$ ).

Interaksi antara desain dan waktu operasi tidak menunjukkan interaksi yang signifikan ( $P$ value $=0,89$ ). Gambar 3(a) menunjukkan bahwa semua tipe desain LBB-AAP mampu mengeliminasi $\mathrm{NH}_{4}{ }^{+}$, dengan kemampuan eliminasi berkisar antara 41,9 $52,1 \%$. Tipe desain $\mathrm{E}$ dan $\mathrm{H}$ lebih baik dibandingkan dengan tipe desain K dan HE. Secara berurutan tingkat efisiensi rata-ratanya adalah $52,1 \pm 8,0,50,4 \pm 5,7,46,9 \pm 5,8$ dan $41,9 \pm 8,2 \%$.

Gambar 3(b) menunjukkan bahwa lamanya waktu operasi atau bertambahnya umur rumput vetiver, maka performa terbaik terjadi pada bulan ke dua. Ini diduga karena dengan bertambahnya lama waktu operasi, maka beban limbah meningkat dan mengakibatkan menurunnya kemampuan eliminasi $\mathrm{NH}_{4}{ }^{+}$. Kemampuan eliminasi $\mathrm{NH}_{4}{ }^{+}$bisa ditingkatkan dengan menambah biomasa tanaman rumput vetiver karena $\mathrm{NH}_{4}{ }^{+}$bisa dimanfaatkan langsung oleh rumput vetiver dan digunakan oleh bakteri aerob sebagai energi.

\section{Efisiensi Penghilangan $\mathrm{NO}_{2}^{-}$}

Keberadaan $\mathrm{NO}_{2}^{-}$dalam air limbah berkisar antara 1,9-4,4 $\mathrm{mg} / \mathrm{L}$ dengan rata-rata sebesar 3,36 mg/L. Hargreaves dan Tucker (2004), menyatakan bahwa akumulasi nitrit bersifat racun terhadap organisme perairan dan jika dibiarkan akan menumpuk dalam sistem produksi perikanan. Nitrit menjadi tinggi akibat dari produk intermediet antara nitrifikasi dan denitrifikasi. Oleh karena itu, keberadaan $\mathrm{NO}_{2}^{-}$harus dieliminasi terlebih dahulu sebelum dipakai kembali (resirkulasi) atau dibuang ke badan perairan penerima. Keberadaan $\mathrm{NO}_{2}^{-}$ dapat membahayakan bagi kelangsungan hidup organisme perairan, baik bagi organisme yang dibudidayakan maupun organisme lainnya yang ada di perairan penerima.

Hasil penelitian menunjukkan efisiensi ratarata eliminasi konsentrasi $\mathrm{NO}_{2}^{-}$mencapai $91,26 \%$ $(\mathrm{SD}=18,89 \%)$. Persentase penghilangan $\mathrm{NO}_{2}^{-}$ tertinggi terjadi pada tipe konstruksi LBB-AAP Hidroponik $(\mathrm{H})$ dan terendah $(51,03 \% \pm 17,99 \%)$ terjadi pada konstruksi LBB-AAP Emergent (E) Gambar 4(a) menunjukkan tingkat eliminasi $\mathrm{NO}_{2}$ dalam berbagai tipe desain sistem LBB-AAP.

Hasil analisis statistik menunjukkan bahwa perlakuan tipe desain LBB-AAP berpengaruh ( $\mathrm{P}$ value $=0,001)$ secara signifikan. Hasil Fisher's test, menunjukkan bahwa tipe desain $\mathrm{HE}$ dan $\mathrm{H}$ tidak berbeda nyata, sedangkan desain $\mathrm{K}$ dan $\mathrm{E}$ secara signifikan berbeda nyata dengan tipe desain $\mathrm{HE}$ dan $\mathrm{H}$. Rata-rata efisiensi eliminasi $\mathrm{NO}_{2}^{-}$tipe desain $\mathrm{K}$ dan $\mathrm{E}$ di bawah $\mathrm{HE}$ dan $\mathrm{H}$. Tingkat efisiensi eliminasi tertinggi terjadi pada tipe desain $\mathrm{H}$, yakni 91,26\%. Eliminasi $\mathrm{NO}_{2}^{-}$tinggi diduga karena terjadi transformasi $\mathrm{NO}_{2}^{-}$menjadi $\mathrm{N}_{2} \mathrm{O}$ melalui proses denitrifikasi. Yang dkk. (2009), nitrit secara umum diakui sebagai faktor penting yang menyebabkan produksi $\mathrm{N}_{2} \mathrm{O}$, yang merupakan keuntungan dari penghapusan nitrogen melalui nitrit.

Perlakuan $\mathrm{K}$, $\mathrm{HE}$ dan $\mathrm{E}$ memiliki tingkat efisiensi eliminasi konsentrasi $\mathrm{NO}_{2}{ }^{-}$sebesar 51,03$65,9 \%$. Kemampuan LBB-AAP, baik K, HE, maupun $\mathrm{E}$ dalam pengendalian limbah budidaya udang vaname dapat ditingkatkan, misalnya dengan modifikasi rasio ukuran kolam-LBB-AAP, penambahan jumlah tanaman, atau penambahan waktu tinggalnya (HRT). Gambar 4(b) menunjukkan bahwa secara umum kemampuan sistem LBB-AAP dalam mengeliminasi $\mathrm{NO}_{2}{ }^{-}$ meningkat dengan bertambahnya lama waktu operasi sistem LBB-AAP. Peningkatan tajam terutama terjadi pada tipe desain hidroponik $(\mathrm{H})$ dan kombinasi hidroponik-Emergent (HE).

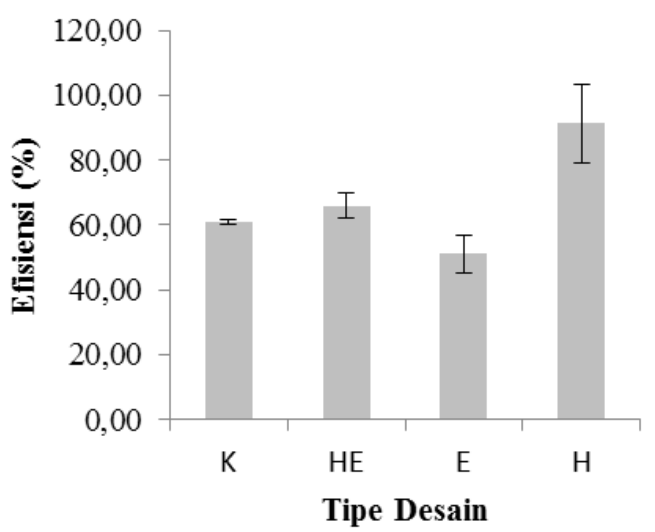

(a)

Gambar 4. (a) Tingkat efisiensi eliminasi $\mathrm{NO}_{2}^{-}$ waktu operasi.

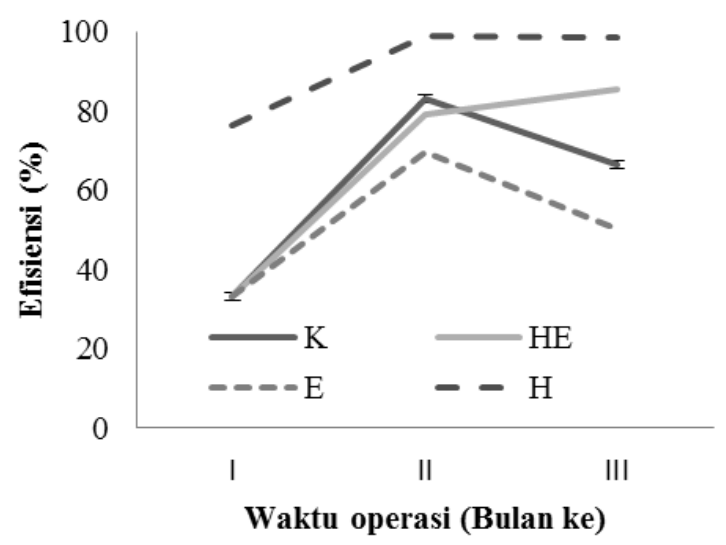

(b) (b) Variasi tingkat efisiensi eliminasi $\mathrm{NO}_{2}^{-}$berdasarkan 


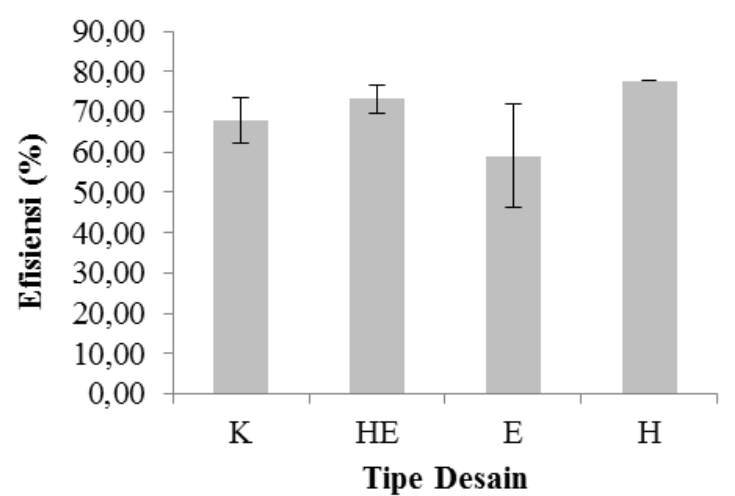

(a)

Gambar 5. (a) Tingkat efisiensi eliminasi $\mathrm{NO}_{3}$ waktu operasi.

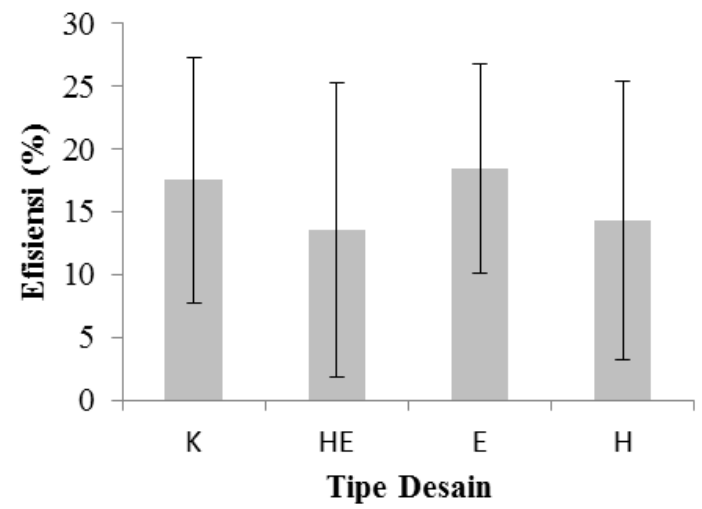

(a)

Gambar 6. (a) Tingkat efisiensi eliminasi $\mathrm{PO}_{4}{ }^{3-}$ waktu operasi.

Perlakuan terhadap waktu operasi memberikan hasil berbeda secara signifikan ( $\mathrm{P}$ value $=0,0002)$. Hasil Fisher's test, menunjukkan eliminasi $\mathrm{NO}_{2}^{-}$ bulan ke satu berbeda nyata dengan bulan ke dua dan tiga, bulan ke dua berbeda nyata dengan bulan ke tiga dan ke satu. Interaksi antara tipe desain dan waktu operasi tidak menunjukkan hasil yang signifikan (P value interaksi Desain-Waktu $(0,43)>$ $\alpha=0.05)$.

Uraian tersebut dapat diberikan kesimpulan bahwa penggunaan LBB-AAP mampu mengeliminasi limbah $\mathrm{NO}_{2}^{-}$dengan efisiensi berkisar antara $51-91 \%$. Kemampuan LBB-AAP dalam penghilangan limbah $\mathrm{NO}_{2}^{-}$ini karena dalam lahan basah terjadi tiga proses yakni fisik, biologi dan kimia. Truong dkk. (2008), menyatakan bahwa penggunaan lahan basah untuk menghilangkan bahan pencemar melibatkan berbagai proses biologi yang kompleks, termasuk proses transformasi mikrobiologi dan fisik-kimia seperti adsorpsi dan sedimentasi. Lee dkk. (2009) serta Tchobanoglous dkk.(2003) menyatakan bahwa penghapusan nitrogen dapat dicapai dengan dua proses, fisikokimia dan teknik pengolahan biologis.

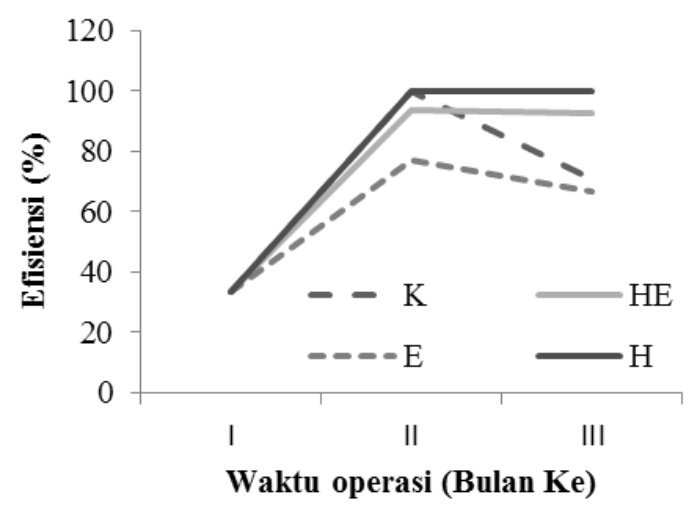

(b)

(b) Variasi tingkat efisiensi eliminasi $\mathrm{NO}_{3}^{-}$berdasarkan

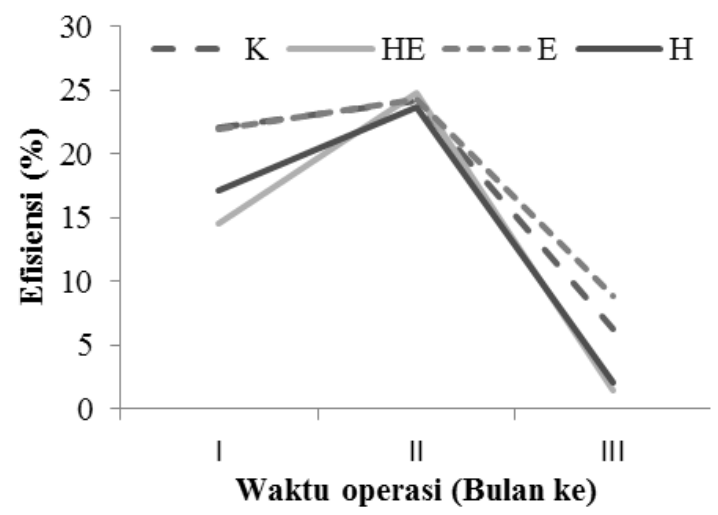

(b)

(b) Variasi tingkat efisiensi eliminasi $\mathrm{PO}_{4}{ }^{3-}$ berdasarkan

Penghapusan nitrogen biologis dari air limbah, terutama terdiri dari kombinasi antara nitrifikasi aerobik dan denitrifikasi anaerobik. Ini biasanya memberikan penyisihan nitrogen yang optimal dan ekonomis.

\section{Efisiensi Penghilangan $\mathrm{NO}_{3}{ }^{-}$}

Nitrat $\left(\mathrm{NO}_{3}{ }^{-}\right)$merupakan hasil akhir dari konversi biologi sisa metabolisme oleh bakteri yang merubah amonia, nitrit menjadi nitrat. $\mathrm{NO}_{3}{ }^{-}$berasal dari aktifitas bakteri nitrobacter atau nitrosomonas dalam mengubah $\mathrm{NH}_{4}{ }^{+}$melalui $\mathrm{NO}_{2}{ }^{-}$menjadi $\mathrm{NO}_{3}{ }^{-}$. $\mathrm{NO}_{3}^{-}$yang terbentuk dimanfaatkan oleh plankton sebagai unsur hara nitrogen dalam kolam. Namun demikian dalam kondisi budidaya intensif biasanya pembentukan $\mathrm{NO}_{3}^{-}$lebih cepat dari pada penyerapan oleh plankton, sehingga $\mathrm{NO}_{3}^{-}$akan menumpuk dan berpotensi terjadi reaksi balik yang memicu pembentukan $\mathrm{NO}_{2}^{-}$(dalam kondisi minim oksigen). Menurut Anonim (1993), denitrifikasi biasanya terjadi pada keadaan oksigen terlarut minim, yakni tidak lebih $0,3-1,5 \mathrm{mg} / \mathrm{L}$. Jika terjadi oksigen terlarut kurang dari $0,3-1,5 \mathrm{mg} / \mathrm{L}$, maka akan terjadi dentrifikasi. Keadaan ini meningkatkan 
konsentrasi $\mathrm{NO}_{2}^{-}$yang bersifat toksik terhadap udang atau biota akuatik lainnya.

Gambar 5(a) menunjukkan tingkat efisiensi rata-rata penghilangan $\mathrm{NO}_{3}^{-}$pada berbagai tipe desain LBB-AAP. Tingkat eliminasi tertinggi sebesar $77,78 \%(\mathrm{SD}=0 \%)$ dan terendah sebesar $58,97 \%$ ( $\mathrm{SD}=12,877 \%)$. Persentase penghilangan tertinggi terjadi pada konstruksi LBB-AAP tipe Hidroponik $(\mathrm{H})$ dan terendah terjadi pada konstruksi LBB-AAP tipe Emergent (E).

Hasil analisis statistik menunjukkan bahwa perlakuan tipe desain LBB-AAP tidak berbeda secara signifikan $(P$ value $=0,065)$. Analisis statistik terhadap umur rumput vetiver memberikan pengaruh secara signifikan ( $\mathrm{P}$ value 0,000$)$. Untuk interaksi antara desain dan waktu operasi tidak menunjukkan interaksi yang signifikan $(\mathrm{P}$ value $0,25)$.

Hasil Fisher's test untuk waktu operasi menunjukkan bahwa eliminasi $\mathrm{NO}_{3}{ }^{-}$berbeda secara signifikan, dengan tingkat efisiensi tertinggi terjadi pada waktu operasi bulan ke dua. Apabila dilihat dari plot faktor utama dari perlakuan desain dan waktu operasi (Gambar 5(a)), maka perlakuan H memiliki tingkat efisiensi lebih baik dibandingkan dengan perlakuan lain (HE, $\mathrm{K}$ dan $\mathrm{E}$ ), dengan tingkat efisiensi masing-masing adalah 77,78; 73,14; 68,00 dan 58,97\%.

Gambar 5(b) menunjukkan bahwa secara umum kemampuan eliminasi $\mathrm{NO}_{3}^{-}$meningkat dengan bertambahnya umur rumput vetiver. Performa terbaik terjadi pada bulan ke dua pengamatan kecuali perlakuan $\mathrm{H}$, di mana performa bulan ke dua dan tiga memiliki performa yang sama. Hasil analisis statistik menunjukkan bahwa penggunaan desain LBB-AAP mampu menghilangkan limbah $\mathrm{NO}_{3}^{-}$dengan efisiensi berkisar antara 58,97-77,78\%.

\section{Efisiensi Penghilangan $\mathrm{PO}_{4}^{3-}$}

Keberadaan $\mathrm{PO}_{4}{ }^{3-}$ dalam tambak merupakan produk sampingan dari sisa pakan udang. $\mathrm{PO}_{4}{ }^{3-}$ dari kolam penelitian budidaya udang vaname (air limbah) dapat mencapai 21,68 $\mathrm{mg} / \mathrm{L}$ (rata-rata $10,67 \mathrm{mg} / \mathrm{L}$ ). Tingkat efisiensi penghilangan limbah $\mathrm{PO}_{4}{ }^{3-}$ dalam LBB-AAP berkisar antara 13,6-18,4\%. Efisiensi penghilangan tertinggi terjadi pada LBBAAP dengan tipe desain Emergent (E) dan terendah pada tipe kombinasi Hidroponik-Emergent (HE) (Gambar 6(a)).
Hasil analisis data statistik menunjukkan bahwa tipe desain LBB-AAP tidak berbeda nyata ( $P$ value $=0,23$ ). Lama waktu operasi terhadap kemampuan eliminasi $\mathrm{PO}_{4}{ }^{3}$ berpengaruh secara signifikan $\left(\mathrm{P}\right.$ value $\left.=4,98 \cdot 10^{-6}\right)$.

Interaksi antara desain dan waktu operasi tidak menunjukkan interaksi yang signifikan ( $\mathrm{P}$ value $=0,81$ ). Gambar 6(a) menunjukkan bahwa semua tipe desain LBB-AAP memiliki kemampuan eliminasi $\mathrm{PO}_{4}{ }^{3-}$ yang rendah, yakni berkisar antara 13,6-18,4\%. Tipe desain sistem E dan K lebih baik dibandingkan dengan $\mathrm{H}$ dan HE. Secara berurutan tingkat efisiensi rata-ratanya adalah $18,4 \pm 1,6$, $17,5 \pm 3,7,14,3 \pm 2,6$ dan $13,6 \pm 4,0 \%$. Gambar 6(b) menunjukkan bahwa bertambahnya umur rumput vetiver tidak menunjukkan peningkatan kemampuan eliminasi $\mathrm{PO}_{4}{ }^{3-}$. Kemampuan eliminasi meningkat dari bulan pertama ke bulan kedua, dan memiliki trend menurun pada bulan ketiga.

Tingkat efisiensi eliminasi $\mathrm{PO}_{4}{ }^{3-}$ yang rendah diduga karena media tanam dan tipe LBB yang digunakan. Greenway dan Woolley (2001), menemukan bahwa serapan tanaman menyumbang 65\% dari influen P. Selanjutnya Arias dkk. (2001) serta Reddy dan D' Angelo (1997), menyatakan bahwa $\mathrm{P}$ dapat mengikat substrat dari adsorpsi dan reaksi pengendapan dengan kalsium $(\mathrm{Ca})$, besi $(\mathrm{Fe})$ dan aluminium (Al). Jadi untuk meningkatkan efisiensi eliminasi $\mathrm{PO}_{4}^{3-}$ perlu dilakukan penambahan unsur $\mathrm{CA}, \mathrm{Fe}$ dan Al. Selain itu perlu dikombinasikan dengan tipe LBB aliran dibawah permukaan. Lin dkk. (2002), lahan basah buatan tipe aliran air permukaan efektif menghilangkan nitrogen dan tipe aliran di bawah permukaan tanah lebih efektif dalam penghilangan fosfat.

\section{Penentuan Tipe Desain Terbaik dengan RaP}

Hasil perhitungan $\mathrm{RaP}$ terhadap parameter $\mathrm{NH}_{3}, \mathrm{NH}_{4}^{+}, \mathrm{NO}_{2}^{-}, \mathrm{NO}_{3}{ }^{-}$dan $\mathrm{PO}_{4}{ }^{3-}$, diperoleh bahwa tipe desain terbaik yang dapat dikembangkan sebagai media penghilangan pencemar adalah sistem LBB-AAP tipe desain Hidroponik diikuti tipe desain emergent tanpa sekat koral, emergent dengan sekat koral dan gabungan hidroponik+emergent (Tabel 4). Namun demikian tipe desain lainnya masih bisa diterapkan untuk pengendalian air limbah budidaya udang vaname dengan melakukan perubahan-perubahan tertentu. Upaya pengendalian air limbah budidaya udang

Tabel 4. Rekapitulasi hasil RaP dalam penentuan tipe desain terbaik.

\begin{tabular}{cccccccc}
\hline Tipe desain & $\mathrm{NH}_{3}$ & $\mathrm{NH}_{4}{ }^{+}$ & $\mathrm{NO}_{2}^{-}$ & $\mathrm{NO}_{3}^{-}$ & $\mathrm{PO}_{4}{ }^{3-}$ & Total & Rangking \\
\hline $\mathrm{K}$ & 26,6 & 26,6 & 57,3 & 31,3 & 13,0 & 154,9 & 2 \\
$\mathrm{HE}$ & 0,0 & 13,3 & 0,0 & 64,6 & 0,0 & 77,9 & 4 \\
$\mathrm{E}$ & 50,0 & 50,0 & 21,6 & 0,0 & 3,3 & 125,0 & 3 \\
$\mathrm{H}$ & 26,6 & 0,0 & 91,0 & 100,0 & 7,3 & 225,0 & 1 \\
\hline
\end{tabular}


dengan sistem lahan basah buatan tipe aliran air.permukaan (LBB-AAP) yang memanfaatkan kemampuan rumput vetiver (C. zizanioides, L) mampu memberikan solusi mitigasi lingkungan dalam pengurangan air limbah budidaya udang yang murah, mudah dan efektif, sehingga para pelaku budidaya yang sebagian besar adalah usaha skala kecil dan menengah dapat menerapkan teknologi ini.

\section{KESIMPULAN}

LBB-AAP dengan tanaman rumput vetiver $(C$. zizanioides, L) terbukti dapat diterapkan untuk pengolahan air limbah budidaya udang vaname dengan kondisi salinitas mesohaline. Serapan rumput vetiver (C. zizanioides, $\mathrm{L}$ ) dalam sistem LBB-AAP terhadap pencemar $\mathrm{NO}_{3}^{-}, \mathrm{NH}_{4}^{+}$dan $\mathrm{PO}_{4}{ }^{3-}$ masing-masing mencapai $28.03,63.2$ dan $82.85 \%$ dari efisiensi LBB-AAP.

Secara umum, kinerja meningkat dengan meningkatnya umur rumput vetiver (C. zizanioides, L). LBB-AAP dengan sistem hidroponik menunjukkan kinerja lebih baik dibandingkan dengan tipe Emergent maupun kombinasi hidroponik-Emergent.

\section{UCAPAN TERIMAKASIH}

Penelitian ini merupakan bagian penting dari proses penyusunan disertasi penulis di Program Studi Pengelolaan Sumberdaya Alam dan Lingkungan, Institut Pertanian Bogor. Penulis menghaturkan terima kasih kepada Kementerian Pendidikan Nasional cq. Direktorat Jenderal Perguruan Tinggi yang telah memberikan beasiswa studi dan Balai Layanan Usaha Produksi Perikanan Budidaya (BLUPPB) Karawang, yang telah memberikan bantuan dan kesempatan kepada peneliti untuk melakukan penelitian.

\section{DAFTAR PUSTAKA}

Anonim, 1993. Design Manual: Nitrogen Control. EPA 625/R-93/010. U.S. EPA Office of Research and Development, Washington D.C.

Anonim, 2011. World Aquaculture 2010. Food and Agriculture Organization Of The United Nations, FAO Fisheries And Aquaculture Technical Paper 500/1, Rome.

Anonim, 2014. Statistik Perikanan Indonesia 2014. Badan Pusat Statistik, Jakarta.

Arias, C.A., Del Bubba, M., dan Brix, H., 2001. Phosphorous Removal by Sands for Use as Media in Subsurface Flow Constructed Reed Beds. J. Water Res., 35:1159-1168.
Avnimelech, Y., 2006. Bio-filters: The Need For An New Comprehensive Approach. Aquacultural Engineering, 34:172-178.

Avnimelech, Y., dan Malka, K., 2009. Evaluation of Nitrogen Uptake and Excretion by Tilapia in Biofloc Tanks, Using ${ }^{15} \mathrm{~N}$ Tracing. Aquaculture, 287:163-168.

Boyd, C.E., 2003. Guidelines for Aquaculture Effluent Management at The Farm-Level. Aquaculture, 226:101-112.

Brix, H., 1997. Do Macrophytes Play a Role in Constructed Treatment Wetlands? Water Science and Technology, 35(5): 11-17.

Crab, R., Avnimelech, Y., Defoirdt, T., Bossier, P. dan Verstraete, W., 2007. Nitrogen Removal Techniques in Aquaculture For a Sustainable Production. Aquaculture, 270:1-14.

Crites, R.W., Middlebrooks, J., dan Reed, Sh.C., 2006. Natural Wastewater Treatment Systems. CRC Press, Boca Raton.

Dumas, A., Laliberte, G., Lessard, P. dan de la Noue, J., 1998. Biotreatment of Fish Farm Effluents Using The Cyanobacterium Phormidium Bohneri. Aquacultural Engineering, 17:57-68.

Emerson, K., Russo, R.C., Lund, R.E. dan Thurston, R.V., 1975. Aqueous Ammonia Equilibrium Calculations: Effect of $\mathrm{pH}$ and Temperature. J. Fish. Res. Board Can., 32(12): 2379-2383.

Fang, Y., Babourina, O., Rengel, Z., Yang, X. dan $\mathrm{Pu}$, P.M., 2007. Ammonium and Nitrate Uptake by The Floating Plant Landoltia Punctata. Annals of Botany, 99(2):365-370.

Garnett, T.P., Shabala, N.S., Smethurst, P.J. dan Newman, I.A., 2003. Kinetics of Ammonium and Nitrate Uptake by Eucalypt Roots and Associated Proton Fluxes Measured Using Ion Selective Microelectrodes. Functional Plant Biology, 30:1165-1176.

Greenway, M., dan Woolley, A., 2001. Changes in Plant Biomass and Nutrient Removal Over 3 Years in Constructed Wetlands in Cairns, Australia. J. Water Sci. \& Tech., 44: 303-310.

Hargreaves, J.A., dan Tucker, C.S., 2004. Managing Ammonia in Fish Ponds. Southern Regional Aquaculture Center (SRAC). SRAC Publication No. 4603.

Kadlec, R.H., dan Wallace, S.D., 2009. Treatment Wetlands Second Edition. CRC Press, Boca Raton.

Lee, C.G., Fletcher, T.D., dan Sun, G., 2009. Nitrogen Removal in Constructed Wetland Systems. Engineering in Life Sciences. 9(1):11-22. 
Lin, C.K., dan Yang, Y., 2003. Minimizing Environmental Impacts of Freshwater Aquaculture and Reuse of Pond Effluents and Mud. Aquaculture, 226:57-68.

Lin, Y.F., Jing, Sh.R., Lee, D.Y., dan Wang, T.W., 2002. Nutrient Removal from Aquaculture Wastewater Using A Constructed Wetlands System. Aquaculture, 209:169-184.

Naylor, R.L., Goldburg, R.J., Primavera, J.H., Kautsky, N., Beveridge, M.C.M., Clay, J., Folke, C., Lubchenco, J., Mooney, H. dan Troell, M., 2000. Effect of Aquaculture on World Fish Supplies. Nature, 405:1017-1024.

Pan, .J, Sun, H., Nduwimana, A., Wang, Y., Zhou, G., Ying, Y. dan Zhang, R., 2007. Hydroponic Plate/Fabric/Grass System for Treatment of Aquacultural Wastewater. Aquacultural Engineering, 37(3):266-273.

Piedrahita, R.H., 2003. Reducing the Potential Environmental Impact of Tank Aquaculture Effluents Through Intensification and Recirculation. Aquaculture, 226:35-44.

Reddy, K.R., dan D'Angelo, E.M., 1997. Biogeochemical Indicators to Evaluate Pollutant Removal Efficiency In Constructed Wetlands. J. Water Sci. and Tech., 35:1-10.

Reddy, K.R., dan Patrick, W.H., 1984. Nitrogen Transformations and Loss in Flooded Soils and Sediments. J. CRC Crit. Rev. Env. Control, 13:273-309.

Ridha, M.T., dan Cruz, E.M., 2001. Effect of Biofilter Media on Water Quality and Biological Performance of The Nile Tilapia Oreochromis Niloticus L. Reared in a Simple Recirculating System. Aquacultural Engineering, 24: 157-166.

Ray, A.J., Lewis, B.L., Browdy, C.L. dan Leffler, J.W., 2010. Suspended Solids Removal to Improve Shrimp (Litopenaeus vannamei) Production and an Evaluation of a Plant-Based Feed in Minimal-Exchange, Superintensive Culture Systems. Aquaculture, 299:89-98.

Schryver, P.D., Crab, R., Defoirdt, T., Boon, N. dan Verstraete, W., 2008. The Basics of Bio-Flocs Technology: The Added Value for Aquaculture. Aquaculture, 277:125-137.

Spellman, F.R., 2004. Mathematics Manual for Water and Wastewater Treatment Plant
Operators. CRC Press LLC, United States of America.

Tchobanoglous G., Burton F.L., Stensel H.D., 2003. Wastewater Engineering : Treatment, Disposal, and Reuse. Mc Graw Hill Inc. New York.

Tosepu, R., 2012. Laju Penurunan Logam Berat Plumbum $(\mathrm{Pb})$ dan Cadmium $(\mathrm{Cd})$ oleh Eichornia Crassipes dan Cyperus Papyrus. J. Manusia \& Lingkungan, 19(1):37-45.

True, B., Johnson, W., dan Chen, S., 2004. Reducing Phosphorus Discharge from FlowThrough Aquaculture III: Assessing High-Rate Filtration Media for Effluent Solids and Phosphorus Removal. Aquacultural Engineering, 32:161-170.

Truong, P., Van, T.T., dan Pinners, E., 2008. The Vetiver System for Prevention and Treatment of Contaminated Water And Land. TVNseries2-2pollution.htm.

Truong, P., dan Hart, B., 2001. Vetiver System for Wastewater Treatment. Technical Bulletin no. 2001/21. Pacific Rim Vetiver Network. Office of the Royal Development Projects Board, Bangkok.

Truong, P., dan Loch, R., 2004. Vetiver System For Erosion And Sediment Control. ISCO 2004 13th International Soil Conservation Organisation Conference - Brisbane, Australia.

Twarowska, J.G., Westerman, P.W., dan Losordo, T.M., 1997. Water Treatment and Waste Characterization Evaluation of an Intensive Recirculating Fish Production System. Aquacultural Engineering, 16:141-147.

Vimala, Y., dan Kataria, S.K., 2004. PhysicoChemical Study of Vetiver in Wetland Soil Reclamation. Dept of Botany, CCS University, Meerut.

Wang, L.K, Tay, J.H., Tay, T.L., dan Hung, Y.T., 2010. Environmental Bioengineering. Volume 11 Handbook of Environmental Engineering. Humana Press, Springer New York.

Yang, Q., Liu, X., Peng, C., Wang, S., Sun, H., dan Peng, Y., 2009. $\mathrm{N}_{2} \mathrm{O}$ Production during Nitrogen Removal via Nitrite from Domestic Wastewater: Main Sources and Control Method. Environmental Science \& Technology, 43(24):9400-9406. 